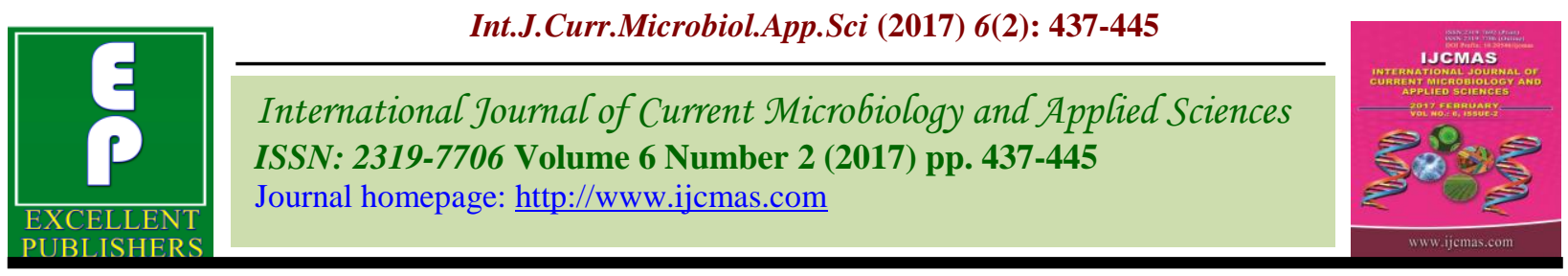

Case Study

http://dx.doi.org/10.20546/ijcmas.2017.602.049

\title{
Case Study on Performance Evaluation of Drip Irrigation Systems in Selected Villages of Guntur District, Andhra Pradesh, India
}

\author{
Y.V. Krishna Reddy ${ }^{1}$, Sirisha Adamala ${ }^{2}$ and Bachina Harish Babu ${ }^{2}$ \\ ${ }^{1}$ Central Research Institute for Dryland Agriculture (CRIDA), Hyderabad, Telangana, India \\ ${ }^{2}$ Department of Applied Engineering, Vignan's Foundation for Science, Technology and \\ Research University (VFSTRU), Vadlamudi (Guntur), Andhra Pradesh, India \\ *Corresponding author
}

A B S T R A C T

The pressurised (drip) irrigation technology and its adoption to meet the food security with increasing water productivity and decreasing evapotranspiration,

Keywords

Emitter, Lateral, Submain, Main line, Horsepower, Total Head, APMIP.

Article Info

Accepted: 12 January 2017 Available Online: 10 February 2017 assured the release of abundant stress of the limited water resources. To increase the agricultural productivity to meet future food challenges and sustain the ground water resources of Andhra Pradesh, the government has launched APMIP (Andhra Pradesh Micro Irrigation Project). APMIP supports the farmer's community welfare with advanced irrigation equipment installation. This case study was taken up to evaluate and assess the performance of the drip irrigation systems in the selected farmer's fields of some villages of Guntur District. The objectives of this study are to evaluate the unequal discharge distribution of emitters of drip irrigation systems and to assess the maintenance conditions of installed systems. Farmers experience revealed that there were some maintenance problems of installed systems in their fields and economical feasibility of these systems at filed level was not adequate. Further, the results showed that the flow variation of some drip irrigation systems ranges from $3-8 \%$, which was accepted $(<10 \%)$ and some were $25-44 \%$, which were not acceptable limits $(<20 \%)$.

\section{Introduction}

Drip irrigation (also known as trickle irrigation or micro irrigation) is an irrigation method, which minimizes the use of water and fertilizer by allowing water drop by drop slowly to the roots of plants, either onto the soil surface or directly onto the root zone, through a network system of valves, pipes, tubing, and emitters. Modern pressurised irrigation technology was invented in Israel by Simcha Blass and his son Yeshayahu.
Instead of releasing water through tiny holes, which blocks easily by tiny particles, water was released through larger and longer passageways by using slow water velocity inside a plastic emitter. The first experimental system of this type was established in 1959, when Blass partnered with Kibbutz Hatzerim to create an irrigation company called Netafim. Together they developed and patented the first practical surface drip irrigation emitter. This method was very 
successful and subsequently spread to Australia, North America, and South America by the late 1960 s.

Water allocation share of agriculture was more in high populated countries like India to ensure enough food for the rising population with existing traditional irrigation methods. It is essential to adopt and develop according to the filed level requirement and apply water saving technology and management methods. A lot of research work has been done on drip irrigation system. Young et al., (1985) stated that drip irrigation of banana crop produced double the yield obtained from a well managed sprinkler irrigation system in Hawaii. Sustainability of food production depends on sound and efficient water use and conservation practices consisting mainly of irrigation development and management. Srinivas and Hegde (1989) demonstrated that drip irrigation was superior to basin irrigation in all aspects of growth and yield of banana and also in water use efficiency in India. The results of this work stated that the productivity was increased by $50.1 \%$ and the water saving of about $44.8 \%$ was increased.

Fertigation units of drip systems are found giving some troubles in some of the farmers' fields and farmers experience some maintenance problems under drip irrigation systems installed in their fields under APMIP (Andhra Pradesh Micro Irrigation Project) due to ground reality approaches like operation and maintenance. Cook and Sanders (1991) examined the effect of fertigation frequency (daily to monthly) on drip-irrigated tomato yields in two South Carolina soils on daily or weekly basis. Results showed that the fertigation significantly increased the yield as compared with monthly fertigation. Major drawback of traditional irrigation methods were excess usage of fertilizers for getting optimum yields. Therefore, there is a necessity to develop modern irrigation technologies with optimum fertilizer utilisation to increase the area under irrigation as well as to enhance agricultural productivity per unit volume of water applied and limited utilisation of resources. Badr and Abou ElYazied (2005) determined that $\mathrm{N}$ rate and fertigation frequency resulted in significant differences in $\mathrm{N}$ uptake, $\mathrm{N}$ recovery and $\mathrm{N}$ use efficiency (NUE). Total $\mathrm{N}$ uptake was appreciable higher with increasing $\mathrm{N}$ rate and with more frequent than with less frequent fertigation. The averaged $\mathrm{N}$ recovery across fertigation frequencies was 60 and $54 \%$ and NUE was 221 and $194 \mathrm{~kg}$ yield/kg N with 200 and $300 \mathrm{~kg} \mathrm{~N} / \mathrm{ha}$ applied respectively.

Soil degradation through soil salinity buildup though the subsurface drip irrigation systems was identified during the review collection interaction with farmers says that there will be little impact of drip in building up soil salinity, a query has been made with the farmers different villages. Badr and Talaab (2007) observed that during the growing season, soil salinity build up tended to increase with the subsurface drip irrigation in the upper and lower parts of the wetted area in comparison to the surface drip irrigation. The growth and yield performance of tomatoes irrigated through subsurface drip was lower when compared with surface drip irrigation in heavy soils. whereas for orchard plantation this challenges were minimised with appropriate measurements in light soils shows some studies Pasternak and De Malach (1995); Bustan et al., (2004) found that Considerable yields were obtained using saline irrigation water $(4-12 \mathrm{dS} / \mathrm{m})$ in crops that had been previously defined as moderately sensitive to salt stress.

The drip-irrigated for planted guava at $6 \times 6$ $\mathrm{m}$, produced $8.31 \mathrm{t} \mathrm{ha}^{-1}$ and $15.0 \mathrm{t} \mathrm{ha}^{-1}$, whereas at $5 \times 5 \mathrm{~m}, 12.0$ and $21.60 \mathrm{t} \mathrm{ha}^{-1}$ after $3^{\text {rd }}$ and $4^{\text {th }}$ year of planting respectively. The guava plants planted at 5 × $5 \mathrm{~m}$ had higher 
irrigation production efficiency $\left(6.79 \mathrm{~kg} \mathrm{~m}^{-3}\right)$ than $6 \times 6 \mathrm{~m}\left(4.70 \mathrm{~kg} \mathrm{~m}^{-3}\right)$. Fruit weight $(161.3 \mathrm{~g})$ and $\operatorname{TSS}\left(11.7^{\circ} \mathrm{B}\right)$ and total sugars $(10.71 \%)$ and vitamin $\mathrm{C}\left(211.40 \mathrm{mg} 100 \mathrm{~g}^{-1}\right.$ pulp) contents were superior in fruits obtained from drip-irrigated systems as compared to flood-irrigated ones. The results indicated that the drip irrigation has a significant role in increasing productivity as well as economic return of guava in saline soil at the planting distance of $5 \times 5 \mathrm{~m}$ plant spacing also supported review of Mandal et al. (2004) in their studies on the effect of drip irrigation system on yield, quality and economic return of guava production in saline soil having $\mathrm{pH}$ 8.18 and EC 0.95 mmhos $\mathrm{cm}^{-1}$ gave the results that the drip irrigated guava plants started bearing at $3^{\text {rd }}$ year of planting, whereas flood irrigated plants after $4^{\text {th }}$ year of planting.

It was found that major crops grown in Guntur district has adopted drip irrigation system from 2005-2012 have increased from $7-32 \%$ for chillies and from 6-16\% for sugarcane. Lahav and Kalmar (1981) reported that drip has proved to be the most successful systems for bananas and grape yards, especially when water is applied very frequently. The area irrigated by low volume (drip/micro sprinkler) has increased by about $33 \%$, while amount of land irrigated by surface methods has decreased by about $35 \%$. In short, drip investment in sugarcane cultivation remains economically viable even without subsidy. Narayanamoorthy and Deshpande (2004) in their studies on drip irrigated sugarcane fields determined that productivity was $23 \%$ higher than that under the flood method of irrigation, with water saving of about $44 \%$ per hectare and electricity saving of about $1059 \mathrm{kWh} / \mathrm{ha}$.

Realizing the importance for economic use of precious ground water for irrigation, the Government of Andhra Pradesh, one of the leading states in India, launched the APMIP, the first of its kind on November $3^{\text {rd }} 2003$. The project is aimed at bringing 2.50 lakh ha area under micro irrigation systems in 22 districts of Andhra Pradesh and is reaching its targets. A farmer is entitled to avail subsidy of $60 \%$ of the drip systems cost $(50 \%$ in case of sprinkler) to the maximum ceiling of Rs. 50,000 . The pre requisites for availing benefit under the project are land ownership, water source and pumping unit. The agencies have been entrusted the task of monitoring and evaluation of micro irrigation systems installed under APMIP were Engineering Staff College of India for Telangana region, Central Research Institute for Dryland Agriculture (CRIDA) for Rayalaseema region and Agricultural Finance Corporation for Coastal Andhra region. APMIP has brought 1.66 lakh ha area under micro irrigation during $2 \frac{1}{2}$ years period with the target being 2.48 ha.

\section{Materials and Methods}

Study area has total geographical area of 11328.238 Sq. $\mathrm{Km} \quad(4.12 \%$ of Andhra Pradesh, which consists of three revenue divisions, 57 mandals and 72 revenue villages). The total rainfall of the district is $851 \mathrm{~mm}$. The soils of the district are broadly classified as black cotton soils (62\%), red sand and loam soils (20\%), Krishna alluvial soils $(15 \%)$ and coastal soils (5\%). A regional APMIP cell is working under the District Water Management Agency (DWMA), in the Guntur district, under the chairmanship of the District Collector.

Selection criteria for performance evaluation of drip irrigation systems is considered based on high percentage installations as well as significant challenges of villages in Mangalagiri and Thullur Mandals of Guntur district. Statistical information about the status of APMIP in Guntur district for the past four years, the performance of the Micro 
Irrigation companies in the district and the success stories of the district under drip irrigation were obtained from the APMIP Regional office, Guntur.

Morteza Orang et al., (2008) conducted a survey on the irrigation methods in California. A one page questionnaire was prepared and mailed to 58000 growers by the California Department of Food and Agriculture. By using the similar format of questionnaire for data collection and performance evaluation of drip irrigation systems methodology adopted from various organizations namely APMIP form many farmers and divided into groups and area allocated under various sectors such as Horticulture, Sericulture and sugarcane. This data is analyzed to know the potential to be created in installing drip systems in various districts under different sectors. The APMIP has insisted all the companies through its regulations that a fertigation unit is mandatory while installing drip systems and their awareness of framers were collected.

As most of the farmers facing problems with drip irrigation after 2-3 years of installation were unequal discharge of emitters from starting of the lateral to end of lateral. Lateral inner and outer diameter were measured and average discharge of the emitters was calculated at the emitters was measured accurately by volumetric method with the help of a 1 liter measuring cylinder and a stopwatch used for the measurement of time required for it. The technical parameters measurement such as pressure variation between the inlet and end plug positions of the selected laterals and discharge variation of the emitters at different locations (initial section, middle section and end section) of the selected laterals. As per the standard practice of drip irrigation system a pressure variation of $20 \%$ though out the system and discharge variation of $8-10 \%$ is allowed in the discharge from the inlet to the end plug of the lateral is allowed in the Indian conditions for the better performance of the systems. To ascertain the same in the fields of about ten farmer's covered with drip system were chosen according to the different levels of land holding extent (from one acre to about 10 acre) and one lateral is randomly chosen in each of the field and the pressure at the inlet end and at the end plug were measured with the help of a pressure gauge.

The readings of emitter discharge and submain discharge were calculated to find the required horse power (HP) of the system. To calculate the size of the motor, the frictional head loss in the laterals, submains, mains has to be observed. To estimate the friction head of drip irrigation laterals, the DarcyWeishbach equation for smooth pipes in micro-irrigation can be combined with the Blassius equation as follows (Schwab et al., 1996):

$\mathrm{H}_{\mathrm{fl}}=\mathrm{K} \times \mathrm{L} \times \mathrm{Q}^{1.75} \times \mathrm{D}^{-4.75} \times \mathrm{F} \ldots \ldots . .(1)$

Where, $\mathrm{H}_{\mathrm{fl}}=$ Friction loss in lateral pipe, $\mathrm{m}$; $\mathrm{K}=\mathrm{A}$ constant whose value is $7.89 \times 10^{5}$ for SI units of water at $20^{\circ} \mathrm{C} ; \mathrm{L}=$ Length of pipe, $\mathrm{m} ; \mathrm{Q}=$ Rate of flow in pipe, $1 / \mathrm{s} ; \mathrm{D}=$ Diameter of the pipe, $\mathrm{mm} ; \mathrm{F}=$ Factor for multiple outlet flow.

The value of $\mathrm{F}$ is generally 0.376 for laterals and 0.389 for submain and $F$ value for main is 1 as the main is not a multiple outlet pipe because it has only a few submain connections. The discharge of the lateral was obtained by dividing the design discharge of the pump (generally 8-12 lps) by number of laterals on the sub main. The number of laterals on the submain can be calculated by dividing the length of submain with the spacing between laterals. The generally adopted spacing between laterals ranges from 1.2-1.5 $\mathrm{m}$ for banana crop in the village where the experimental work was conducted. And 
the spacing between the drippers (inline) is $0.6 \mathrm{~m}, 0.8 \mathrm{~m}$ and $1 \mathrm{~m}$ for banana crop. The above Eq. (1) can be used to estimate the head loss due to friction in submain and mains also, which vary from lateral in all the aspects of length, diameter and discharge as suggested by Giuseppe et al. (2005). Generally, the discharge of both the main and submain are same and equal to the value of the pump discharge.

The friction head in submain and main lines were denoted with $\mathrm{H}_{\mathrm{fs}}$ and $\mathrm{H}_{\mathrm{fm}}$ respectively. The length and diameter of the submain and main and laterals are measured in the field with the help of measuring tape and digital callipers, respectively. The calliper meter was used to measure the diameter of the pipes. The pressure head required to operate the farthest emitter ranges between 6-12 m. In general, the pressure head required to operate the farthest emitter is regarded as the operating pressure of the system and is taken as $10 \mathrm{~m}$. The head loss due to bends, filters etc. is taken as $1.5 \mathrm{~m}$ for the whole drip irrigation system. The maximum pressure drop in the screen filter is specified as 0.3-0.5 $\mathrm{m}$. And the pressure drop in the fertigation tank generally depends on the capacity of the fertigation tank and also on the type of the fertilizer used for fertigation. Then the total head requirement of the system is calculated as:

$\mathrm{H}_{\text {sys }}=$ Head required for operation + friction loss + bend losses + filter loss

$\mathrm{H}_{\mathrm{sys}}=\mathrm{H}_{\mathrm{o}}+\mathrm{H}_{\mathrm{fl}}+\mathrm{H}_{\mathrm{fs}}+\mathrm{H}_{\mathrm{fm}}+\mathrm{h} \ldots \ldots$... (2)

Where, $\mathrm{H}_{\mathrm{o}}=$ head required to operate the system, $\mathrm{m} ; \mathrm{H}_{\mathrm{fl}}=$ total head loss due to friction in the lateral, $\mathrm{m} ; \mathrm{H}_{\mathrm{fs}}=$ total head loss in the submain, $\mathrm{m} ; \mathrm{h}=$ head loss due to bends, filters losses etc. The friction losses in the suction pipes are generally taken as $6 \mathrm{~m}$ per $100 \mathrm{~m}$ pipe as proposed by Al-Ghobari (2005). The suction in the Lingayapalem village where the study is conducted ranges from $40 \mathrm{ft}(13 \mathrm{~m})$ to
$65 \mathrm{ft}(20 \mathrm{~m})$. Majority of the pumps were installed with a suction head is 13-18 m. The velocity head in the suction and delivery pipes is assumed as $0.15 \mathrm{~m}$. Therefore, the total head required for the pump is calculated as:

$\mathrm{H}_{\text {Total }}=\mathrm{H}_{\mathrm{sys}}+\mathrm{H}_{\mathrm{s}}+\mathrm{h}_{\mathrm{fs}}+\mathrm{H}_{\mathrm{d}}+\mathrm{H}_{\mathrm{v} .}+\mathrm{h}_{\mathrm{fd}}$

Where, $\mathrm{H}_{\text {sys }}=$ Total head requirement of the system, $\mathrm{m} ; \mathrm{H}_{\mathrm{s}}=$ Total suction head, $\mathrm{m} ; \mathrm{h}_{\mathrm{fs}}=$ friction losses in suction pipe, $\mathrm{m} ; \mathrm{H}_{\mathrm{d}}=$ Delivery head, $\mathrm{m} ; \mathrm{h}_{\mathrm{fd}}=$ friction losses in delivery pipe, $\mathrm{m} ; \mathrm{H}_{\mathrm{v}}=$ Velocity head, $\mathrm{m}$.

The delivery head and the friction losses due to delivery head in drip irrigation systems were zero as there is no tank constructed to deliver the water. Then, the size of the pumping unit can be estimated as:

$h p=\frac{Q \times H}{75 \times \eta_{p} \times \eta_{m}}$

hp $=$ Horse power of the electric motor driving the pump, HP; $\mathrm{H}=$ Total head requirement of the pump, $\mathrm{m} ; \mathrm{Q}=$ Capacity of the drip irrigation system, $1 / \mathrm{s} ; \eta_{\mathrm{p}}=$ efficiency of the pump, fraction; $\eta_{\mathrm{m}}=$ efficiency of the motor, fraction.

The combined efficiency of pump and motor is assumed as $95 \%$ as all the pumps used are centrifugal monobloc directly coupled to the motor drive.

\section{Results and Discussions}

The results of analysis of performance evaluation carried out in the fields of farmers of different villages (such as Lingayapalem, Rayapudi, Kaza, Venkatapalem, Mandadam, Nuthakki and Needamarru) and the random samplings were named as shown in table 1. The data from the Venkatapalem village reveals that the mostly cultivated crop in the area is banana, chillies and cotton due to its 
tradition practices in the region and also due to its market driven condition. The extent of area of selected samples were obtained with different ranges land holdings (from 1 acre to 8 acres) and various types of pumps (like high speed submersible) of different capacities, which were installed at the fields.

Ah Koon et al., (1990) investigated the effect of drip discharge rate on the water content distribution beneath a crop of sugarcane and they found that increasing the discharge rate resulted in an increased lateral movement of water and a decrease in the wetted depth. The result from table 1 showed that the discharge variations were under the acceptable limits of less than $10 \%$. Whereas the pressure drops of different fields were also under acceptable conditions, out of the ten fields inspected, two fields proved the best with pressure variation between $12 \%$ and $20 \%\left(\mathrm{~F}_{3}\right.$ and $\left.\mathrm{F}_{2}\right)$. The other seven fields, except field $\mathrm{F}_{8}$ were in the acceptable range with the pressure drop of 20 to $40 \%$. The field $\mathrm{F}_{8}$ is beyond the standards with poor performance having a pressure drop of $44 \%$ (low pressure of $0.9 \mathrm{~kg} / \mathrm{cm} 2$ at the inlet and $0.5 \mathrm{~kg} / \mathrm{cm} 2$ at the end plug position). Discharge of drippers of all the fields showed in table 1 has a little variation from the rated discharge and the variation of discharge is less than $10 \%$. Samples of $F_{1}, F_{3}, F_{5}$ and $F_{10}$ had almost equal discharge at location 1 (dripper at inlet of lateral) to location 3 (dripper at end plug of the lateral) rate of discharges of $4.0 \mathrm{lph}, 3.0 \mathrm{lph}, 3.0 \mathrm{lph}$ and 4.0 lph, respectively.

The length and diameter of the main, submain and laterals which were measured in the selected fields of drip systems is shown in table 2. It also contains the rated discharge of the emitters (Emitter Q) and the measured pump discharge (Pump Q) at the flushing end of the submain. It is clear that the rated discharge for most of the inline drippers is 3.0 lph and $4.0 \mathrm{lph}$. The length of the main, submain and laterals generally depends on the design of the system. Some of the drip systems contain a long submain, which is divided into three or four parts according to the design convenience and requirements of valves to operate certain parts of the field at a particular time. And some of the drip systems e.g. $\mathrm{F}_{6}$ does not contain submain and all the laterals were run from a single main line. The evaluation of technical parameters was taken up to check whether the operation of the drip systems is under the limits of the standards or not. The literature provides the information that a pressure drop $20 \%$ in the lateral indicates the optimum performance of the system and a variation of $20-40 \%$ is acceptable for the operation of the system. The variation of $10 \%$ in the rated discharge is acceptable for a drip system (Al-Ghobari, 2005).

With the help of the data reported in the table 3 , the different pressure head losses in the drip systems of the selected fields was calculated by using the equations 1, 2 and 3 . The main line pipe diameter used in the design of the drip systems of the selected fields range from of the 3 inch to $3.5 \mathrm{inch}$. And the diameter of the submain pipes generally range from 2.5-3 inches and the laterals are generally available with the diameter of 12 and $16 \mathrm{~mm}$. The frictional head in the laterals is higher for the fields of large area, having the length of the laterals more than $50 \mathrm{~m}$. The laterals of length below $40 \mathrm{~m}$ have medium pressure head of 0.5-1.5 $\mathrm{m}$. The friction head in the submain is mainly dependent on the length of the submain and the inner diameter of the submain in most of the fields was almost $57 \mathrm{~mm}$. Similarly the head loss in the main is also dependent on the length as the diameter and rated discharge through the main is almost equal for all the selected fields.

The basic principle of drip irrigation system is the operating pressure of the system should be about $10 \mathrm{~m}$; pressure drop in the filters, 
fertigation tanks and pressure drop due to bends and fittings are regarded nearly equal to all the fields with slight variation according to the extent of the field.

Table.1 Pressure and discharge measurements in the experimental fields

\begin{tabular}{|c|c|c|c|c|c|c|c|c|}
\hline \multirow[b]{2}{*}{ Sl. No. } & \multirow[b]{2}{*}{$\begin{array}{c}\text { Field } \\
\text { No. }\end{array}$} & \multicolumn{4}{|c|}{ Discharge (lph) } & \multicolumn{3}{|c|}{ Pressure $\left(\mathrm{kg} / \mathrm{cm}^{2}\right)$} \\
\hline & & $\begin{array}{c}\text { Location } 1 \\
\text { (Inlet) }\end{array}$ & $\begin{array}{c}\text { Location } 2 \\
\text { (Middle) }\end{array}$ & $\begin{array}{l}\text { Location } 3 \\
\text { (End plug) }\end{array}$ & $\begin{array}{c}\text { Discharge } \\
\text { drop (\%) }\end{array}$ & $\begin{array}{c}\text { At } \\
\text { Inlet }\end{array}$ & $\begin{array}{l}\text { End } \\
\text { plug }\end{array}$ & $\begin{array}{l}\text { Pressure } \\
\text { drop }(\%)\end{array}$ \\
\hline 1. & $\mathrm{~F}_{1}$ & 4.0 & 3.8 & 3.8 & 5.0 & 1.0 & 0.75 & 25 \\
\hline 2. & $\mathrm{~F}_{2}$ & 3.0 & 2.9 & 2.9 & 3.3 & 1.2 & 0.9 & 20 \\
\hline 3. & $\mathrm{~F}_{3}$ & 3.0 & 3.0 & 3.0 & 0.0 & 1.25 & 1.1 & 12 \\
\hline 4. & $\mathrm{~F}_{4}$ & 3.8 & 3.8 & 3.6 & 5.3 & 1.1 & 0.8 & 27 \\
\hline 5. & $\mathrm{~F}_{5}$ & 4.0 & 3.9 & 3.8 & 5.0 & 1.2 & 0.9 & 25 \\
\hline 6. & $\mathrm{~F}_{6}$ & 3.8 & 3.7 & 3.5 & 7.9 & 1.0 & 0.6 & 40 \\
\hline 7. & $\mathrm{~F}_{7}$ & 3.8 & 3.7 & 3.7 & 2.6 & 1.1 & 0.7 & 36 \\
\hline 8. & $\mathrm{~F}_{8}$ & 3.7 & 3.5 & 3.5 & 5.4 & 0.9 & 0.5 & 44 \\
\hline 9. & $\mathrm{~F}_{9}$ & 3.8 & 3.8 & 3.7 & 2.6 & 1.0 & 0.7 & 30 \\
\hline 10. & $\mathrm{~F}_{10}$ & 4.2 & 4.0 & 4.0 & 4.8 & 1.2 & 0.8 & 33 \\
\hline
\end{tabular}

Table.2 Diameter and lengths of laterals, sub-mains and mains of the drip irrigation systems

\begin{tabular}{|c|c|c|c|c|c|c|c|c|c|c|}
\hline \multirow{2}{*}{$\begin{array}{l}\text { Sl. } \\
\text { No. }\end{array}$} & \multirow{2}{*}{$\begin{array}{l}\text { Plot } \\
\text { No. }\end{array}$} & \multirow{2}{*}{$\begin{array}{c}\text { Area } \\
\text { (acre) }\end{array}$} & \multirow{2}{*}{$\begin{array}{c}\text { Emitter } \\
\text { Q } \\
(\mathrm{lph})\end{array}$} & \multirow{2}{*}{$\begin{array}{c}\text { Pump } \\
\text { Q } \\
(1 / s)\end{array}$} & \multicolumn{3}{|c|}{ Diameter (mm) } & \multicolumn{3}{|c|}{ Length (m) } \\
\hline & & & & & Main & Submain & Lateral & Main & Submain & Lateral \\
\hline 1. & $\mathrm{~F}_{1}$ & 3.0 & 4.0 & 8.2 & 80 & 57 & 12 & 120 & 50 & 54 \\
\hline 2. & $\mathrm{~F}_{2}$ & 2.0 & 3.0 & 7.6 & 80 & 57 & 12 & 40 & 50 & 40 \\
\hline 3. & $\mathrm{~F}_{3}$ & 1.0 & 3.0 & 7.9 & 68 & 57 & 12 & 20 & 50 & 40 \\
\hline 4. & $\mathrm{~F}_{4}$ & 4.0 & 4.0 & 8.4 & 80 & 57 & 16 & 50 & 40 & 49 \\
\hline 5. & $\mathrm{~F}_{5}$ & 1.5 & 4.0 & 7.9 & 80 & 57 & 12 & 10 & 60 & 50 \\
\hline 6. & $\mathrm{~F}_{6}$ & 3.5 & 4.0 & 8.4 & 80 & 57 & 16 & 80 & 0 & 49 \\
\hline 7. & $\mathrm{~F}_{7}$ & 4.0 & 4.0 & 8.2 & 80 & 57 & 16 & 56 & 71 & 56 \\
\hline 8. & $\mathrm{~F}_{8}$ & 4.25 & 4.0 & 7.8 & 80 & 57 & 16 & 144 & 72 & 60 \\
\hline 9. & $\mathrm{~F}_{9}$ & 4.5 & 4.0 & 7.7 & 80 & 57 & 16 & 80 & 100 & 40 \\
\hline 10 & $\mathrm{~F}_{10}$ & 5.0 & 4.0 & 8.3 & 80 & 68 & 16 & 100 & 60 & 60 \\
\hline
\end{tabular}


Table.3 Requirements of the drip irrigation system pump HP calculations

\begin{tabular}{|c|c|c|c|c|c|c|c|c|c|c|}
\hline \multirow{2}{*}{ S1. No. } & Plot. & \multirow{2}{*}{$\begin{array}{c}\text { Area } \\
\text { No. }\end{array}$} & \multirow{2}{*}{ Existing $\mathrm{HP}$} & \multicolumn{6}{|c|}{ Frictional head $(\mathrm{m})$} & \multirow{2}{*}{ Calculated HP } \\
\cline { 5 - 10 } & & & $\mathrm{H}_{\mathrm{fm}}$ & $\mathrm{H}_{\mathrm{fs}}$ & $\mathrm{H}_{\mathrm{fl}}$ & $\mathrm{H}_{\mathrm{sys}}$ & $\mathrm{H}_{\mathrm{s}}$ & $\mathrm{H}_{\text {total }}$ & \\
\hline 1. & $\mathrm{~F}_{1}$ & 3.0 & 3.0 & 1.86 & 1.57 & 0.9 & 14.9 & 13.0 & 28.00 & 2.83 \\
\hline 2. & $\mathrm{~F}_{2}$ & 2.0 & 3.0 & 0.42 & 1.6 & 1.45 & 14.37 & 13.0 & 27.37 & 2.66 \\
\hline 3. & $\mathrm{~F}_{3}$ & 1.0 & 3.0 & 0.3 & 1.6 & 1.5 & 13.0 & 13.0 & 25.00 & 2.66 \\
\hline 4. & $\mathrm{~F}_{4}$ & 4.0 & 3.0 & 1.5 & 2.2 & 1.0 & 16.2 & 15.0 & 31.20 & 3.50 \\
\hline 5. & $\mathrm{~F}_{5}$ & 1.5 & 3.0 & 1.33 & 1.65 & 0.35 & 13.33 & 13.0 & 26.33 & 2.77 \\
\hline 6. & $\mathrm{~F}_{6}$ & 3.5 & 3.0 & 0 & 2.16 & 1.4 & 15.06 & 15.0 & 30.10 & 3.40 \\
\hline 7. & $\mathrm{~F}_{7}$ & 4.0 & 3.0 & 1.33 & 2.34 & 2.0 & 17.17 & 15.0 & 32.20 & 3.50 \\
\hline 8. & $\mathrm{~F}_{8}$ & 4.25 & 3.0 & 2.4 & 2.3 & 4.6 & 20.8 & 15.0 & 35.80 & 3.72 \\
\hline 9. & $\mathrm{~F}_{9}$ & 4.5 & 3.0 & 2.8 & 3.3 & 2.8 & 20.40 & 15.0 & 35.40 & 3.67 \\
\hline 10. & $\mathrm{~F}_{10}$ & 5.0 & 5.0 & 1.05 & 1.4 & 2.24 & 16.2 & 18.0 & 34.20 & 3.80 \\
\hline
\end{tabular}

The total head requirement of the pump for operation of the system is given in the table 3 with information accompanied of different head loss under different sections (such as the laterals, main and submain). It is clear that the total head required for a system is proportional to the area of the field.

For the fields $F_{1}, F_{2}, F_{3}$ and $F_{5}$, the size of the pump is sufficient to operate the system as the existing pump HP is greater than actually required pump HP, which proved that the design of the drip system is authentic. For the remaining fields the required HP to operate the system is slightly more than the presently existing HP. But in the case of the drip system of field $F_{8}$, the actually required pump size is more than the presently installed pump size by about $25 \%$, which results in the overall poor performance of the system with low pressure head build up, large variation of pressure between the lateral inlet and end plug positions of the lateral.

In conclusion, the overall results of the study while interaction with the farmers has revealed that many of the farmers have got benefited by the use of water saving through drip irrigation and cultivation of land holdings was increased about 55-60\%. The drip irrigation system has not only lowered the water consumption but also increased the quality and quantity of the produce as the water is applied in a right quantity at the right time and the cost of cultivation was lowered by reducing the different operational costs by $25-40 \%$ such as (weeding, quantity of fertilizer application, manpower for irrigation and fertiliser application). The discharge variation of F6 and pressure variation of F8 systems arises due inefficient fulfillment of management practices (timely acid treatment, flushing of laterals and cleaning of filters) and unavailability of enough horsepower of pump, respectively. With the use of the drip system, there will be early fruit bearing stage, which provides a better chance for the cultivation of other crops in the second season.

\section{References}

Alberts, A.J. and Robinson, J.C. 1987. The influence of under canopy sprinkler and drip irrigation systems on growth and 
yield of bananas (Cultivar Williams) in the tropics. Scientia Horticulturae, 32: 49-56.

Badr, M.A. and Abou El Yazied, A.A. 2007. Effect of fertigation frequency from subsurface drip irrigation on tomato yield grown on sandy soil. Australian $J$. Basic and Appl. Sci., 1(3): 279-285.

Badr, M.A. and Taalab, A.S. 2007. Effect of drip irrigation and discharge rate on water and solute dynamics in sandy soil and tomato yield. Australian J. Basic and Appl. Sci., 1(4): 545-552.

Ewemoje, T.A. and Lateef, S.A. 2006. Performance evaluation of drip irrigation system using sweet corn. $J$. Appl. Sci. Engi. Technol., 6(1): 16-21.

Giuseppe, P., Domenico, P., and Pietro, D. 2005. Simplified procedure to evaluate head losses in drip irrigation laterals. $J$. Irrigation and Drainage Engi., 131: 525-532.

Hegde, D.M. and Srinivas, K. 1989. Growth, yield, nutrient uptake and water use of banana crops under drip and basin irrigation with $\mathrm{N}$ and $\mathrm{K}$ fertilization, Tropical Agriculture (Trinidad), 68: 331-334.
Juana, L.R. Aguez-Sinobas, L. and Alberto, L. 2002. Determining minor head losses in drip irrigation laterals $\mathrm{I}$ : Methodology. J. Irrigation and Drainage Engi., 128: 376-384.

Lahav, E. and Kalmar, D. 1981. Shortening the irrigation interval as a means of saving water in a banana plantation. Australian J. Agri. Res., 32: 465-467.

Mandal, G. and Kumar, R. 2004. Effect of drip irrigation and plant spacing on yield, quality and economic return of guava (psidium guajava 1.) grown in saline soil. SHS Acta Horticulturae, 735: International Guava Symposium.

Moteza, N.O., Scott, J.M. and Snyder, R.L. 2008. Survey of irrigation methods in California in 2001. J. Irrigation and Drainage Engi., 143(1): 96-100.

Narayanamoorthy, A. 2004. Impact assessment of drip irrigation in India: the case of sugarcane. Development Policy Review, 22(4): 443-462.

Young, S.C.H., Sammins, T.W. and Wu, I. 1985. Banana yield as affected by deficit irrigation and patterns of lateral layouts. Transactions of ASAE, 28: 507510.

\section{How to cite this article:}

Krishna Reddy, Y.V., Sirisha Adamala and Bachina Harish Babu. 2017. Case Study on Performance Evaluation of Drip Irrigation Systems in Selected Villages of Guntur District, Andhra Pradesh, India. Int.J.Curr.Microbiol.App.Sci. 6(2): 437-445.

doi: http://dx.doi.org/10.20546/ijcmas.2017.602.049 